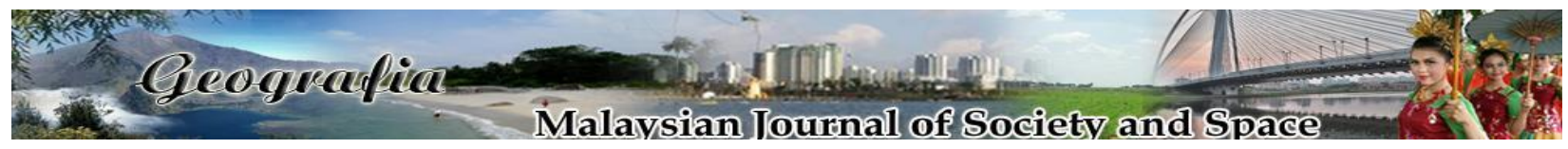

\title{
Brexit dan Referendum Keahlian Kesatuan Eropah 2016: Implikasi terhadap landskap politik United Kingdom
}

\author{
Mohd Irwan Syazli Saidin \& Muhammad Alif Azrai Norizan \\ Centre for Research in History, Politics, and International Affairs, \\ Faculty of Social Sciences and Humanities, Universiti Kebangsaan Malaysia \\ Correspondence: Mohd Irwan Syazli Saidin (email: irwansyazil@ukm.edu.my)
}

Received: 21 August 2020; Accepted: 16 February 2021; Published: 27 February 2021

\begin{abstract}
Abstrak
Artikel ini meneliti implikasi Brexit dan Referendum Keahlian Kesatuan Eropah (EU) 2016 terhadap lanskap politik United Kingdom. Perbincangan kajian meliputi sejarah perkembangan isu Brexit, latar belakang Referendum 2016 serta analisis keputusan pilihan pengundi dan beberapa isu politik post-truth yang menjadi perdebatan pasca referendum. Kajian dijalankan menggunakan kaedah pemerhatian langsung serta analisis dokumen primer dan sekunder seperti warta rasmi kerajaan, Hansard parlimen, laporan media dan badan penyelidikan bebas, kenyataan pemimpin politik dan penulisan ilmiah. Keputusan referendum memperlihatkan pendirian rakyat UK yang berbelah bahagi di mana 51.9 peratus pengundi memilih untuk UK meninggalkan keahlian EU dan menyokong kempen Brexit manakala 48.1 peratus mahu UK kekal sebagai ahli EU. Dapatan kajian menjelaskan terdapat beberapa faktor utama yang menyumbang kepada kerencaman pola pengundian rakyat UK terhadap keputusan referendum iaitu perbezaan lokaliti dan demografi, jurang pendidikan dan tahap sosio-ekonomi, perbezaan pendirian pemimpin kanan parti politik utama di England dan Scotland serta pengaruh sentimen Euroscepticism, khusus terhadap polemik jumlah sumbangan tahunan UK kepada EU dan ancaman Islamisasi melalui penyertaan Turki sebagai ahli baharu EU. Kemenangan kempen Leave pasca Referendum 2016 meninggalkan dua kesan utama kepada lanskap politik UK. Pertama, berlaku peningkatan terhadap populariti dan aktivisme parti politik dan gerakan haluan kanan seperti UK Independence Party (UKIP), British National Party (BNP) dan English Defence League (EDL). Kedua, perkembangan politik populisme yang didorong oleh sentimen xenofobia dan Islamofobia dilihat semakin berleluasa sebagai kempen untuk menarik sokongan rakyat disamping turut menyumbang kepada peningkatan kadar jenayah kebencian (hate-crime) yang disasarkan kepada golongan minoriti dan imigran.
\end{abstract}

Kata Kunci: Implikasi, pasca Brexit, politik United Kingdom, populism, post-truth, Referendum EU 2016 


\title{
Brexit and the 2016 European Union Membership Referendum: Implication on United Kingdom political landscape
}

\begin{abstract}
This article examines the implication of Brexit and the 2016 European Union (EU) membership referendum on United Kingdom (UK) political landscape. Discussion includes historical development of Brexit, background to the 2016 Referendum as well as analysis on voters' choices and several debated issues of post-truth politics in the post-referendum. The study was conducted via direct observation and analysis of primary and secondary documents, such as official records, Hansard, independent body and media reports, political statements and academic publication. The referendum outcome reveals split standpoints within the UK citizens as 51.9 percent voters had opted the UK to leave the EU membership and supported Brexit campaign, while 48.1 percent voters wanted to remain. The findings explain key contributed factors of diversed votes by the citizens among which are locality and demography, education gap and socio-economic level, attitudes of main party leaders in England and Scotland, as well as the influence of Euroscepticism sentiment, especially on the polemics of UK annual contribution to the EU and Islamisation threat via Turkey-EU membership accession. The success of Leave campaign leaves two major political consequences. First, there has been an increase in popularity and activism of far right parties and movements, for instance the UK Independence Party (UKIP), the British National Party (BNP) dan the English Defence League (EDL). Secondly, the development of populism politics, driven by xenophobia and Islamophobia, is seen to have gained momentum to attract general support, apart from contributing to the increased hate-crime rates that targeting minorities and immigrants.
\end{abstract}

Keywords: Implication, post Brexit, United Kingdom politics, populism, post-truth, 2016 EU referendum

\section{Pengenalan}

Tanggal 23 Jun 2016 menyaksikan rakyat United Kingdom (UK) telah diberi mandat untuk menentukan masa depan UK sebagai negara anggota Kesatuan Eropah (European Union, EU). Perdebatan mengenai keahlian UK dalam badan supranasional itu ditentukan dengan satu soalan mudah: "Should the United Kingdom remain a member of the European Union or leave the European Union?". Soalan ini menjadi perbincangan bertahun-tahun dalam kalangan masyarakat UK malah merentasi generasi, wilayah, blok politik dan pertalian keluarga. Pilihan 51.9 peratus pengundi untuk keluar daripada EU sememangnya mengejutkan banyak pihak dan dilihat sebagai satu langkah menongkah arus globalisasi dalam konteks dunia tanpa sempadan, hubungan antarabangsa dan ekonomi pasaran bebas. Melihat kepada kesignifikanan Referendum Keahlian UK dalam EU pada Jun 2016, kajian ini meneliti beberapa persoalan utama seperti berikut; 1) Apakah latarbelakang referendum yang telah dijalankan dan bagaimanakah ia boleh berlaku?; 2) Apakah isu dan sentimen yang dibangkitkan?; 3) Siapakah aktor utama berserta pendirian mereka?; 4) Sejauhmanakah sokongan warga UK merentas wilayah, negeri dan demografi terhadap isu Brexit?; 5) Bagaimanakah keputusan akhir referendum menidakkan ramalan awal 
pelbagai kaji selidik?; dan yang terakhir 6) Apakah implikasi pasca referendum terhadap pergerakan politik pelampau kanan serta perkembangan politik populisme di UK?.

Persoalan-persoalan ini akan dirungkai berdasarkan pemerhatian langsung pengkaji semasa berada di UK di antara tahun 2014 sehingga 2018 dan menerusi analisis dokumen bersumberkan warta rasmi kerajaan UK, laporan badan penyelidikan, kenyataan ahli politik menerusi media tempatan UK, bahan ilmiah dan kajian akademik. Bahagian awal artikel ini menghuraikan latar belakang Referendum 2016, diikuti bahagian kedua yang menjelaskan faktor penyumbang kepada kerencaman pola pengundian, manakala bahagian akhir menganalisis implikasi Brexit terhadap lanskap politik UK dengan memfokuskan kepada beberapa isu utama iaitu kebangkitan pergerakan kumpulan pelampau kanan (far-right movements), populariti parti berhaluan kanan dan serta peningkatan sentimen populisme, Euroscepticism, xenofobia dan Islamofobia.

\section{Latar belakang Referendum Keahlian UK dalam EU 2016}

Brexit (frasa yang digabungkan daripada perkataan 'Britain' dan 'Exit' yang merujuk kepada usaha melepaskan keahlian UK dalam EU) merupakan isu yang sudah berlanjutan sejak UK menyertai EU atau pada ketika itu dikenali sebagai European Economic Community (EEC) pada tahun 1973. Selepas menyertai EEC, timbul dakwaan bahawa terma perjanjian penyertaan tersebut tidak menguntungkan UK. Maka Harold Wilson (bekas Perdana Menteri UK 1964-1976) telah memberi komitmen untuk menilai semula perjanjian di antara UK dengan EEC serta memberi peluang kepada rakyat untuk menentukan sama ada UK kekal di dalam atau keluar daripada badan ini (May, 1999). Pada 5 Jun 1975, satu referendum telah diadakan dengan soalan; "Do you think that the United Kingdom should stay in the European Community (the Common Market)?". Sebanyak 67 peratus pengundi telah memilih untuk memberikan mandat kepada Wilson agar terus dikekalkan keahlian UK dalan EEC. Hampir tiga dekad selepas referendum Brexit yang pertama, persoalan mengenai keahlian UK dalam EU dilihat masih mempunyai momentum apabila David Cameron (bekas Perdana Menteri UK 2010-2016), menerusi ucapan beliau dalam satu majlis anjuran Parti Konservatif (Conservative Party) di London pada 2013 kembali membangkitkan isu ini. Petikan berikut menjadi titik tolak terhadap usaha mengadakan referendum tiga tahun selepas itu.

Simply asking the British people to carry on accepting a European settlement over which they have had little choice is a path to ensuring that when the question is finally put - and at some stage it will have to be - it is much more likely that the British people will reject the EU. That is why I am in favour of a referendum. I believe in confronting this issue shaping it, leading the debate. Not simply hoping a difficult situation will go away (Petikan ucapan David Cameron, dalam The Guardian, 2013)

Berikutan usaha yang dibangkitkan oleh Cameron, Parti Konservatif telah memutuskan untuk mendraf Rang Undang-Undang Referendum EU bertarikh 14 Mei 2013 untuk dibahas dalam parlimen. Antara isi kandungan utama draf tersebut ialah satu referendum mesti diadakan sebelum 31 Disember 2017 untuk menentukan kelangsungan keahlian UK dalam EU oleh seluruh warganegara (BBC News, 2013). Agenda referendum ini telah berjaya melepasi ke peringkat House of Commons sebagai Rang Undang-Undang persendirian pada November 2013 melalui 
James Wharton (ahli parlimen Parti Konservatif) dan akhirnya diluluskan sebagai akta parlimen pada 17 Disember 2015.

\section{Keputusan referendum}

Keputusan referendum yang berlangsung pada 23 Jun 2016 sememangnya memeranjatkan semua pihak. Dalam referendum tersebut, 17.4 juta pengundi atau 51.9\% rakyat UK memilih untuk keluar daripada keahlian EU sementara 48.1 peratus atau 16.1 juta memilih untuk kekal (Jadual 1).

Jadual 1. Keputusan Referendum EU 2016

\begin{tabular}{lcc}
\hline & Jumlah Undi & Peratus (\%) \\
\hline Leave & $17,410,742$ & 51.9 \\
Remain & $16,141,241$ & 48.1 \\
Undi Rosak & 25,359 & 0.1 \\
Keluar mengundi & $33,577,342$ & 72.2 \\
\hline
\end{tabular}

Sumber: House of Commons (2016)

Keputusan referendum tersebut amat mencerminkan kerencaman politik UK merentasi lapisan masyarakat, wilayah, negeri, generasi, sosio-ekonomi dan parti politik. Peratusan keluar mengundi yang tinggi ditafsirkan sebagai kesungguhan rakyat dalam menentukan masa depan UK, dan dilihat sebagai satu titik pertembungan penting di antara kelangsungan amalan demokrasi berteraskan pilihan utama rakyat atau keperluan integrasi regional (Eropah) demi kepentingan strategik negara. Beberapa faktor telah dikenal pasti sebagai penyumbang kepada keputusan Referendum 2016. Antaranya adalah seperti lokaliti, sosio-ekonomi, demografi, peranan parti politik, jurang pendidikan dan politik post-truth yang memanipulasi isu berkaitan EU.

\section{Faktor penyumbang kepada pola pengundian referendum}

\section{Perbezaan merentas negeri dan wilayah}

Jika diteliti keputusan referendum mengikut wilayah dan daerah tempatan, perbezaan pendirian antara kempen Leave dan Remain adalah amat jelas. Antara faktor utama ialah kepelbagaian populasi di wilayah-wilayah dan negeri di UK. Kota metropolitan seperti London yang merupakan pusat perkembangan ekonomi dan pentadbiran mengalami kebanjiran imigran yang lebih pesat jika dibandingkan dengan wilayah lain. Malah jika dilihat sejarah penghijrahan imigran ke UK pasca perang dunia kedua (1945), London sendiri mempunyai jumlah imigran yang terbesar berbanding bandar-bandar utama di seluruh UK. Kehadiran imigran memberi imbangan kepada populasi masyarakat London. Dalam satu bancian penduduk pada 2011, diversiti penduduk pelbagai etnik lebih jelas kelihatan di kawasan London Raya jika dibandingkan dengan wilayahwilayah lain seperti dalam Jadual 2. Berdasarkan statistik Jadual 2, dapat dirumuskan bahawa kecenderungan untuk berlakunya integrasi antara masyarakat pelbagai etnik adalah lebih kuat di kawasan yang mempunyai populasi imigran yang besar, berbanding kawasan yang dihuni oleh majoriti penduduk 'white British'. Hal ini selari dengan keputusan Referendum mengikut wilayah di mana majoriti pengundi di bahagian Greater London memilih Remain berbanding sebahagian 
besar wilayah England yang lain. Namun timbul satu lagi persoalan, mengapa Ireland Utara dan Scotland, meskipun memiliki kependudukan kulit putih lebih tinggi memilih untuk Remain dan tidak seperti mereka yang berada di wilayah England yang lain.

Jadual 2. Peratusan penduduk kulit putih dan lain-lain keturunan antara wilayah di United Kingdom, 2011

\begin{tabular}{lllll}
\hline Wilayah & Putih & \% & Lain-Lain & \% \\
\hline Midlands Timur & $4,046,356$ & 89.26 & 486,866 & 10.74 \\
England Timur & $5,310,194$ & 90.82 & 536,771 & 9.18 \\
London Raya & $4,887,435$ & 59.79 & $3,286,506$ & 40.20 \\
England Timur Laut & $2,475,567$ & 95.33 & 121,319 & 4.67 \\
England Barat Laut & $6,361,716$ & 90.21 & 690,461 & 9.79 \\
Ireland Utara & $1,779,750$ & 98.28 & 30,863 & 1.72 \\
Scotland & $5,084,407$ & 96.02 & 210,996 & 3.98 \\
England Tenggara & $7,827,820$ & 90.65 & 806,930 & 9.35 \\
Wales & $2,928,253$ & 95.59 & 135,203 & 4.41 \\
Midlands Barat & $4,663,669$ & 82.71 & 968,178 & 17.28 \\
Yorkshire dan Humber & $4,691,956$ & 88.80 & 591,777 & 11.20 \\
England Barat Daya & $5,046,429$ & 95.41 & 242,506 & 4.59 \\
\hline Suan & & & &
\end{tabular}

Sumber: Office of National Statistics (2011)

Dalam perspektif Scotland, harus diingat bahawa Parti Kebangsaan Scotland (SNP) menyapu bersih hampir kesemua kerusi Parlimen Scotland sewaktu Pilihanraya Umum 2015 (Green \& Prosser, 2016). Pandangan terhadap isu-isu berkaitan Eropah di Scotland juga adalah jauh berbeza dengan apa yang dilihat dalam sudut pandang sebahagian besar masyarakat di England. Pada ketika Referendum EU dijalankan, Scotland masih segar daripada peristiwa Referendum Kemerdekaan (untuk menjadi sebuah negara bebas tanpa ikatan dengan UK) pada 18 September 2014. Tidak sampai setahun kemudian, SNP mencatat kemenangan besar dalam Pilihanraya Umum 2015. Sebagai sebuah parti yang pro kepada Eropah, dan kritikal terhadap polisi pro-England parti-parti utama di UK, SNP berpendirian bahawa Scotland mempunyai masa depan yang lebih baik jika kekal bersama EU dan hasrat ini hanya boleh tercapai jika Scotland merdeka secara mutlak daripada pentadbiran London (Engström, 2018). Scotland juga dilihat lebih terbuka dalam hal-hal berkaitan imigran di mana Civic-nationalism dan dasar imigran SNP yang menerima pelarian Syria secara tidak langsung telah menggalakkan perkembangan positif multiculturalism (BBC News, 2019).

\section{Perbezaan merentas sosioekonomi dan demografi masyarakat}

Dalam perspektif generasi, secara keseluruhannya mereka yang lahir sebelum UK menyertai EU adalah lebih cenderung untuk memilih Leave. Begitulah sebaliknya bagi generasi dan golongan belia yang lahir pasca 1973. Hal ini dijelaskan oleh Ashcroft (2016) dalam satu tinjauan pada hari referendum menganggarkan bahawa 60 peratus responden yang berumur 65 tahun dan ke atas cenderung mengundi Leave - jauh berbeza jika dibandingkan dengan 73 peratus responden yang berumur 18 hingga 24 tahun dan mengundi Remain. Keadaan ini secara tidak langsung berakar umbi kepada soal identiti nasional di mana bagi pengundi lanjut usia, mereka melihat bahawa identiti dan tradisi 'Great' Britain itu harus dipelihara dan tidak dicemari unsur-unsur lain khususnya elemen multiculturalism dan pan-Europanism.

Bagi kelompok pengundi tersebut, kemegahan UK pra 1973 mesti dikembalikan di mana pada hemat mereka, UK berhak membuat keputusan dan dasar sendiri tanpa campur tangan oleh 
badan luar, khususnya parlimen EU. Perbezaan yang wujud di antara dua generasi ini banyak dipengaruhi oleh nilai sosial. Mereka yang lebih berusia melihat liberalisasi sosial sebagai sesuatu yang negatif - maka undi Leave adalah reaksi spontan terhadap kemerosoton nilai-nilai progresif Britain (Norris, 2018). Bagi golongan ini, tradisi konservatif Britain yang bertunjangkan 'ketamadunan orang putih' dilihat terancam akibat pertembungan budaya, agama dan etnik yang pelbagai. Malahan dalam tinjauan yang sama oleh Ashcroft, sekurang-kurangnya 70 peratus pengundi Leave melihat elemen liberalisme sosial, globalisasi, internet, imigran dan sebagainya sebagai 'a force for ill vote' untuk mengembalikan semula ancaman identiti asal Britain pra kebanjiran imigran. Pola pengundian referendum turut menampakkan perbezaan antara penduduk metropolitan berbanding penduduk luar bandar khususnya di England. Jika diteliti keputusan mengikut kesemua 382 kawasan mengundi di UK, majoriti kawasan bandar utama seperti Bristol, Warwick, Fulham, London, Liverpool, Norwich, Manchester, Oxford dan Cambridge telah mengundi Remain. Hal ini berbeza jika dibandingkan dengan kawasan di luar bandar yang rataratanya mengundi Leave seperti Boston, Cornwal, Hartlepol, Mansfield, Middlesbrough, Stokeon Trent, dan Blackpool (Financial Times, 2016).

Manifestasi jelas daripada keputusan referendum adalah bagaimana penduduk di kawasan luar bandar merasakan bahawa mereka ketinggalan daripada pelbagai sudut khususnya ekonomi jika dibandingkan dengan penduduk di bandar tumpuan perindustrian dan pentadbiran. Kemenangan kempen Leave semasa referendum tersebut adalah suatu gelombang protes daripada pengundi luar bandar yang mahukan suara mereka didengari. Mereka merasakan bahawa penduduk luar bandar tidak dilayan secara adil oleh pemerintah. Gaya hidup dan budaya 'white English' pada sisi pandang mereka mula terancam dengan perkembangan multiculturalism yang banyak tertumpu di bandar utama meskipun luar bandar merupakan punca utama kepada perkembangan ekonomi berasaskan pertanian dan perladangan di UK. Maka, bertitik tolak daripada sentimen ini, kebanyakan penduduk luar bandar mula beralih kepada parti-parti politik berhaluan kanan dan Eurosceptic untuk meluahkan ketidakpuasan hati mereka. Tambahan pula, masyarakat luar bandar sebenarnya telah mula mengekspresikan kemarahan mereka seawal 1990an dengan beberapa penubuhan gerakan berhaluan kanan di kawasan-kawasan 'white English town' (Reed, 2015).

\section{Perbezaan pendirian di antara parti politik utama}

Referendum 2016 memperlihatkan perbezaan jelas di antara pendirian pemimpin dan parti-parti utama di UK. Dalam satu tinjauan kaji selidik oleh Ashcroft (2016), beliau menggunakan asas undi pada Pilihanraya Umum 2015 untuk melihat sejauh mana kecenderungan parti-parti politik utama kepada Remain atau Leave. Hasil yang diperoleh menunjukkan berlakunya perbezaan pendirian dalam kalangan parti-parti ini. Contoh paling jelas adalah Parti Konservatif yang memerintah UK pada ketika itu. Menurut Ashcroft (2016), daripada lebih 4,500 responden yang mengundi Parti Konservatif sewaktu Pilihanraya Umum 2015, 58 peratus mengundi Leave jika dibandingkan dengan 42 peratus yang mengundi Remain. Hal ini demikian kerana meskipun secara rasminya kerajaan UK pimpinan Cameron cenderung untuk kekal di dalam EU, namun beliau tetap memberi keizinan kepada keseluruhan anggota kabinet pada ketika itu untuk bebas menyertai kempen Leave atau Remain tanpa melibatkan soal tanggungjawab secara kolektif. Kelonggaran itu digunakan sepenuhnya oleh beberapa anggota kabinet seperti Michael Gove, Priti Patel dan mantan Datuk Bandar London, Boris Johnson untuk menyebelahi kempen Leave. 
Dalam membahaskan perkara ini, Moore (2016) menganalisis beberapa faktor yang menjadi penentu bagaimana seseorang ahli parlimen dan penyokong Parti Konservatif itu memilih untuk mengundi Leave atau Remain. Pertama adalah penerimaan ideologi konservatisme dan nasionalisme yang dilihat mempunyai kesalinghubungan dengan Euroscepticism. Hal ini bermakna mereka yang mengundi Leave lebih cenderung untuk menentang perkahwinan sejenis, pengguguran bayi secara sah dan menyokong pelaksanaan semula hukuman mati. Apabila usaha Brexit ini dilihat berhubung kait dengan nasionalisme, maka sebahagian besar ahli parlimen Konservatif yang mempunyai pengalaman ketenteraan lebih cenderung untuk mengundi Leave. Justifikasi hujah ini adalah mereka yang pernah berkhidmat dalam ketenteraan mempunyai kecenderungan terhadap nilai nasionalisme dan patriotisme yang lebih tinggi berbanding masyarakat awam. Kedua, seperti mana dalam kalangan pengundi itu sendiri, pendidikan amat memainkan peranan dalam penentuan sokongan terhadap Leave atau Remain. Lanjut Moore, ahli parlimen dan penyokong Parti Konservatif yang berlatarbelakangkan pendidikan tinggi, terutamanya graduan Universiti Oxford, Universiti London dan Universiti Cambridge adalah lebih cenderung untuk mengundi Remain jika dibandingkan dengan ahli parlimen yang tidak mempunyai latar belakang pendidikan universiti.

Pengundi dalam kalangan Parti Buruh pula dalam minggu-minggu menjelang Referendum 2016 berdepan kekeliruan sama ada untuk mengundi Remain atau Leave. Walaupun secara kolektifnya majoriti ahli parlimen dan pengundi Parti Buruh mengambil pendirian untuk kekal di dalam EU, tetapi beberapa tokoh dan pemimpin kanan Parti Buruh seperti Dennis Skinner, yang terkenal dengan jolokan Beast of Bolsover dan John Mann memilih untuk berkempen kepada Leave. Situasi ini secara langsung telah mendatangkan paradoks dalam kalangan penyokong dan kepimpinan Parti Buruh itu sendiri (Johnston et al., 2020). Menurut Haarop (2017), Jeremy Corbyn dan pendokong beliau adalah pro-EU tetapi beberapa pimpinan akar umbi Parti Buruh lebih cenderung untuk bersikap anti-EU. Hal ini menjelaskan bahawa perpecahan dalaman Parti Buruh juga menyumbang kepada faktor pengundian referendum, di mana 70 peratus pengundi Parti Buruh memilih Remain tetapi secara kontradiktif, lebih 70 peratus kawasan parlimen yang dikuasai Parti Buruh adalah dimenangi oleh kempen Leave.

\section{Jurang pendidikan}

Keputusan Referendum EU juga menampakkan perbezaan jelas dari sudut latar belakang pendidikan di mana ia turut mempengaruhi sama ada seseorang itu cenderung untuk menyokong kempen Remain atau Leave. Menurut Curtice (2016):

Education is, of course, linked to social class. Someone with a degree is quite likely to be in a professional or managerial occupation, while someone without any qualifications at all is most likely employed in a routine or semi-routine (working class) occupation. However, the differences in referendum vote choice by social class are less marked than those in respect of education (Curtice, 2016).

Berdasarkan Jadual 3, jelas dilihat perbezaan antara pengundi Remain dan Leave mengikut tahap pendidikan terakhir. Mereka yang menamatkan pengajian di peringkat ijazah dan ke atas lebih cenderung untuk memilih Remain sedangkan mereka yang mempunyai pendidikan rendah atau tanpa latar belakang pendidikan kebanyakannya mengundi Leave. Pengundi Leave jika diselidiki lebih mempunyai unsur-unsur nasionalisme dan lebih fokus kepada hal-hal yang 
berkaitan UK semata-mata. Justeru, kebarangkalian untuk mengetahui atau terlibat dalam integrasi bersama EU menerusi platfom pendidikan, khusus di universiti adalah rendah. Hal ini berbeza jika dibandingkan dengan mereka yang mempunyai latar pendidikan yang lebih baik di mana pengalaman dan pendedahan terhadap nilai-nilai kosmopolitan di kampus seperti kebebasan individu, pluralisme, multiculturalism dan sebagainya yang dilihat selari dengan empat asas kebebasan dalam Kesatuan Eropah adalah lebih kukuh (Gabel \& Palmer, 1995).

Jadual 3. Peratusan undi Referendum mengikut tahap pendidikan

\begin{tabular}{ccc}
\hline Tahap Pendidikan & Remain (\%) & Leave $(\%)$ \\
\hline Ijazah & 78 & 22 \\
Pendidikan Tinggi bawah Ijazah & 47 & 53 \\
A-Level & 59 & 41 \\
GCSE Gred A-C & 38 & 62 \\
GCSE Gred D-E & 31 & 69 \\
Tiada & 28 & 72 \\
\hline
\end{tabular}

Sumber: Curtice (2016)

Kebebasan bergerak untuk bekerja, menyambung pengajian, melancong dan sebagainya memberi lebih peluang kepada golongan terpelajar di UK untuk berintegrasi dengan komuniti Eropoah dan antarabangsa dan seterusnya berupaya memperbaiki kedudukan dan interaksi sosial. Kontradik dengan pengundi yang tidak berpelajaran tinggi, mereka merasakan bahawa tiada manfaat ketara yang diterima oleh UK menerusi keahlian dalam EU, selain menambahkan masalah kebanjiran imigran dan pelarian tidak terkawal dari Eropah dan luar UK. Situasi ini sememangnya telah dimanfaatkan oleh kempen Leave dengan frasa 'Take Back Control!' untuk menyakinkan pengundi bahawa usaha melepaskan keahlian dalam EU adalah perjuangan masyarakat terpinggir di luar bandar dan merupakan suatu usaha untuk mengawal semula kedaulatan UK.

\section{Politik post-truth dalam referendum}

Sepanjang tempoh kempen Brexit, pengamalan politik post-truth dalam menanggapi realiti sebenar di sebalik hal-hal terkait keahlian UK dalam EU dilihat menyumbang kepada keputusan Referendum 2016. Daripada momokan Project Fear hinggalah dakwaan dan sanggahan mengenai hubungan UK dan EU dari segi ekonomi dan sosial, ianya telah dijadikan sebagai bahan utama dalam kempen dan hujah kedua-dua belah pihak Remain dan Leave. Post-truth atau diterjemahkan secara kasar sebagai politik pasca-benar, menurut Keyes (2004), adalah suatu keadaan di mana penipuan adalah lebih berleluasa di dalam dunia yang dipandu oleh media. Lanjut beliau lagi, sirisiri retorik dan dakwaan palsu mula dilihat sebagai sesuatu yang boleh diterima dalam beberapa keadaan tanpa prejudis dan tidak lagi ditolak oleh masyarakat. Malah berdasarkan penjelasan Harsin (2018), strategi memancing emosi pengundi amat memainkan peranan dalam post-truth politics. Elemen paling jelas dalam politik pasca-benar adalah sesuatu dakwaan atau falasi disebut berulang-ulang kali dan hujah yang membatalkan dakwaan tersebut tidak dipedulikan hingga ke satu tahap dakwaan tersebut itu diterima sebagai satu fakta. Perkara ini acap kali digunakan semasa Referendum 2016 menerusi dua contoh isu popular iaitu berhubung bajet tahunan UK kepada EU dan sentimen Islamofobia menerusi polemik keahlian Turki dalam EU. 


\section{Jumlah bajet tahunan UK kepada EU}

Antara dakwaan yang paling popular digunakan semasa kempen Referendum 2016 adalah anggaran belanjawan UK kepada EU sebanyak 350 juta Pound Sterling seminggu. Angka ini banyak digembar-gemburkan dalam poster kempen Leave dan sering disebut berulang-ulang kali oleh Boris Johnson, Nigel Farage dan pimpinan pro kempen Leave. Mereka menarik pengundi untuk menyokong kempen Leave dengan frasa "We send the EU $£ 350 m$ a week". Kenyataan ini banyak terpampang di bas-bas awam, papan tanda dan di poster-poster kempen Leave. Ia bersandarkan kepada hujah bahawa sumbangan tahunan UK kepada belanjawan EU pada 2015 adalah sebanyak 17.8 bilion Pound Sterling.

Namun demikian jelas Henley (2016), angka tersebut hanya bersifat hipotetikal memandangkan sejak 1984, UK hanya perlu menyumbang tidak sampai 1 peratus daripada KDNK tahunan kepada belanjawan EU. Malah anggaran tersebut tidak termasuk rebat kepada sektor awam di UK. Dokumen belanjawan UK dalam EU sendiri menganggarkan sumbangan bersih UK kepada belanjawan EU 2015 hanyalah sekitar 8.5 bilion Pound Sterling atau 162.5 juta Pound Sterling seminggu, dua kali ganda lebih rendah daripada dakwaan oleh kumpulan pendokong kempen Leave. EU sendiri telah memberi sumbangan sekitar 4.4 bilion Pound Sterling kepada Perbendaharaan UK untuk disalurkan kepada sektor swasta dan petani serta ke kawasan-kawasan berpendapatan rendah seperti Cornwall dan Selatan Wales.

Walau bagaimanapun, dakwaan ini terus digunapakai oleh kempen Leave dengan alasan bahawa jika UK memilih untuk keluar daripada EU, peruntukan tersebut akan disalurkan untuk pendanaan National Health Service (NHS) atau Perkhidmatan Kesihatan Nasional yang dilihat lebih kritikal dan layak. Hal ini menyebabkan berlakunya konflik dalam pentadbiran kerajaan apabila Pengerusi UK Statistics Authority pada ketika itu, Sir David Nogrove menuduh Boris Johnson sebagai pemimpin kanan kerajaan telah menyalahgunakan statistik rasmi negara. Dakwaan sedemikian hampir-hampir mencalarkan reputasi Boris Johnson apabila didakwa di mahkamah atas tuduhan menipu yang kemudiannya digugurkan oleh Mahkamah Tinggi UK. Di sini dapat dilihat dengan jelas peranan penting yang dimainkan oleh amalan politik post-truth dalam mempengaruhi keputusan Referendum 2016. Dominic Cummings, salah seorang pimpinan kempen Leave pernah mengakui bahawa jika dakwaan tersebut tidak digunakan, dihebahkan apatah lagi dipaparkan di dinding-dinding kenderaan pengangkutan awam, masyarakat UK berkemungkinan besar akan mengundi untuk kekal di dalam EU (The Independent, 2018).

\section{Keahlian Turki dalam EU}

Satu lagi isu popular yang dibangkitkan semasa kempen Referendum EU adalah mengenai kemasukan Turki sebagai anggota baharu EU. Polemik ini dieksploitasi sepenuhnya oleh kempen Leave untuk mewajarkan hujahan bahawa UK harus meninggalkan EU. Situasi ini secara tidak langsung mendorong kepada isu agama, kaum dan toleransi etnik menjadi sasaran untuk mempengaruhi pengundi dalam kempen Brexit. Hujah penyokong kempen Leave adalah jika Turki diterima untuk menganggotai EU, maka UK akan terdedah kepada gelombang penghijrahan Muslim yang baharu dan meningkatkan risiko kepada perkembangan Islamisasi dan penularan radikal Islam. Tidak cukup dengan itu, timbul dakwaan bahawa jutaan imigran dari luar Eropah berpotensi menjadikan Turki sebagai pintu masuk ke UK jika Ankara diterima menyertai EU memandangkan kadar kelahiran rakyat Turki dan kemasukan pelarian ke negara tersebut adalah amat tinggi. Malah dalam satu video yang tersebar luas di media sosial semasa kempen Brexit, 
UKIP mendakwa bahawa Turki akan menyertai EU pada 2020 dan 15 juta penduduk Turki akan masuk ke wilayah EU dalam tempoh 10 tahun pertama, selain memanipulasi unsur-unsur Islamofobia dan perkauman untuk menarik sokongan pengundi.

Namun jika diikuti proses perundingan Turki untuk menjadi sebahagian daripada negara anggota EU, amat jelas bahawa ianya agak sukar dan hampir mustahil meskipun menjelang 2030 memandangkan proses memenuhi syarat 'acquis communautaire' yang agak rumit dan perlahan. Selain itu, hasrat Turki untuk menganggotai EU turut mendapat tentangan keras daripada beberapa buah negara anggota pengasas seperti Jerman dan Perancis dan negara yang pernah bernaung di bawah kuasa empayar Turki Uthmaniah seperti kelompok negara Balkan (kecuali Bosnia Herzegovina). Malah Presiden Suruhanjaya EU, Jean Claude Juncker berikrar untuk tidak sama sekali menerima permohonan keanggotaan Turki. Menurut beliau:

This is why, under my Presidency of the Commission, ongoing negotiations will of course continue, and notably the Western Balkans will need to keep a European perspective, but no further enlargement will take place over the next five years. As regards Turkey, the country is clearly far away from EU membership. A government that blocks Twitter is certainly not ready for accession (Juncker, 2014)

\section{Impak Referendum 2016 terhadap landskap politik UK}

\section{Populariti parti politik dan gerakan berhaluan kanan}

Dekad 1990an menyaksikan perkembangan besar dalam spektrum politik antarabangsa dan UK juga tidak terkecuali daripada menerima tempiasnya. Keahlian UK dalam EU serta perubahan demografik masyarakat UK memperlihatkan aktiviti pelampau kanan yang lebih terbuka dalam apa yang disebut sebagai cubaan mengekang globalisasi dan memelihara nilai-nilai Inggeris (Hayton, 2016). Tiga parti dan gerakan utama dalam tempoh ini ialah UKIP, British National Party (BNP) dan English Defence League (EDL). Pasca Referendum 2016 berjaya meningkatkan populariti parti dan kumpulan ini meskipun peranan mereka tidaklah begitu besar dalam arena politik tempatan. Gerakan-gerakan pelampau kanan hanya benar-benar menonjol dalam beberapa bulan menuju tarikh Referendum 2016.

Antara peristiwa penting yang menjadi bahan kempen pendokong pelampau kanan adalah seperti polemik 'Islamisasi London' menerusi pelantikan Sadiq Khan sebagai Datuk Bandar London, peristiwa pembunuhan Lee Rigby, seorang anggota tentera UK di Woolwich, London serta beberapa insiden keganasan di luar UK seperti peristiwa 'Charlie Hebdo' di Perancis 2015 dan tragedi rempuhan trak di Berlin 2016. Kesemua peristiwa ini telah dikaitkan dengan imigran Muslim untuk menjustikasikan agenda 'kawalan semula negara'. EDL sebagai contoh semakin popular dengan siri demonstrasi yang kadangkala berakhir dengan pertempuran. Braouezec (2016) menganggarkan sebanyak 10 hingga 15 demonstrasi telah diadakan setiap tahun dengan kehadiran antara 100 hingga 3000 sepanjang tahun 2009 hingga 2015, dan beranggapan bahawa ia akan terus meningkat lebih-lebih lagi sejak kemenangan kempen Leave dalam Referendum 2016. Kajian daripada Tony Blair Institute for Global Change (2019) turut mendapati bahawa tahun 2016 menyaksikan peningkatan mendadak perdebatan mengenai pergerakan pelampau kanan di Parlimen UK dan ianya banyak disumbang oleh perbahasan yang berhubung kait secara tidak langsung dengan Referendum 2016. 
Malah jika diamati perkembangan media sosial baharu (Facebook, Instagram dan Twitter), gerakan pelampau kanan seperti UKIP, BNP dan EDL dilihat bergiat aktif dalam tempoh beberapa minggu menjelang referendum dan lebih agresif setelah kekalahan kempen Remain pasca Referendum 2016. Menurut Smith dan Colliver (2016), akaun Twitter Britain First telah menyaksikan peningkatan jumlah pengikut hampir 1,000 orang di antara 16 hingga 24 Jun 2016. Namun lanjut Smith dan Colliver, peningkatan jumlah pengikut tidak semestinya membawa konotasi kepada sokongan kepada gerakan tersebut memandangkan kandungan komen dan respon netizen adalah bercampur baur di antara sokongan dan kritikan.

\section{Peningkatan sentimen populisme, xenofobia dan Islamofobia}

Nationalistic populism atau right wing populism ditakrifkan sebagai suatu ideologi yang menggabungkan politik sayap kanan serta retorik dan tema-tema yang bersifat populis (Camus dan Leoburg, 2017). Antara ciri utama retorik tersebut ialah sentimen anti-elitis, penentangan terhadap the establishment (kumpulan dominan) serta ditonjolkan sebagai mereka yang bercakap bagi pihak the common people (kumpulan massa) (Roodujin, 2014). Beergren dan Neergard (2015) menulis bahawa apa sahaja yang berkaitan dengan populisme berhaluan kanan ini ditunjangi elemen xenofobia, sentimen anti-imigran, nativisme dan etnonasionalisme. Pendek kata, ia boleh disifatkan sebagai pemeliharaan identiti penduduk asal sesbuah negara. Berbeza dengan pelampau kiri yang menentang kuasa-kuasa korporat, pelampau kanan lebih menjurus kepada penentangan terhadap kebanjiran orang-orang asing di negara mereka (Akkerman, 2003). Populisme menurut Stanley (2008) hanyalah sebuah 'thin ideology' yang memerlukan ideologi lain untuk melengkapinya iaitu fasisme, liberalisme dan sosialisme. Populisme dengan mana-mana gabungan ideologi akan bertukar daripada sebuah gerakan yang secara positif menghidupkan perbincangan politik yang matang kepada suatu bahaya yang mengundang konflik, penindasan secara autoritarian dan keganasan asalkan mengikut suara dan kehendak 'rakyat'.

Bagi parti beracuan populis nasionalis seperti UKIP, agenda populisme berasaskan ketuanan masyarakat kulit putih di UK memerlukan 'political correctness' yang telah dimanifestasi dalam Referendum 2016 (Deacon \& Wring, 2016; Tournier-Sol, 2015; Iakhnis, et al., 2018). Mereka yang terpengaruh dengan idea-idea populisme ini lazimnya menetap di kawasan luar bandar di mana jurang pendapatan, tahap pendidikan dan kelas sosial adalah jauh berbeza dengan populasi penduduk di bandar-bandar utama. Hal ini mendorong kepada sikap eksklusivisme dan ketiadaan integrasi antara masyarakat pelbagai latar belakang (Freeden, 2016). Isu Brexit secara tidak langsung menyumbang kepada peningkatan sentimen perkauman yang telah digerakkan oleh kumpulan pelampau kanan seperti EDL dan rata-ratanya menyasarkan kumpulan etnik minoriti, imigran dan masyarakat Muslim (Allen, 2011; Busher, 2018).

Pasca Referendum 2016 telah menyaksikan peningkatan terhadap jenayah kebencian (hate-crime) yang melibatkan masyarakat minoriti di UK. The Guardian (2019) dalam satu kaji selidik pada February 2019 menjelaskan bahawa 71 peratus masyarakat minoriti terkesan dengan diskriminasi dan hate-crime pasca referendum. Data ini menunjukkan peningkatan sebanyak 13 peratus jika dibandingkan dengan 58 peratus pada Januari 2016, kira-kira lima bulan sebelum referendum. Data ini disahkan melalui laporan Home Office (2018) yang menyaksikan peningkatan konsisten jenayah kebencian di England dan Wales sejak 2011. Mengambil contoh serangan Darren Osborne ke atas Masjid Finsbury Park pada 2017, pelaku jenayah kebencian ini mula disemai dengan nilai Islamofobia dan ideologi kanan ekstrem beberapa minggu sebelum serangan berlaku, hasil daripada pengaruh bahan-bahan anti-Islam yang diakses melalui media. 
Peranan pelampau kanan dalam serangan tersebut juga terserlah apabila perbicaraan di mahkamah mendapati Osborne menerima dan membaca mesej daripada pemimpin EDL iaitu Tommy Robinson dan Jayda Fransen serta mengikuti akaun media sosial kumpulan pelampau kanan sebelum melancarkan serangan beliau dengan cara memandu laju sebuah van dan merempuh sekumpulan pengunjung Masjid Finsbury Park di jalan raya berhampiran (The Times, 2018).

\section{Kesimpulan}

Keputusan Referendum EU 2016 telah menunjukkan wajah sebenar politik UK yang rencam. Hampir 52 peratus rakyat UK yang telah mengundi untuk keluar daripada EU jelas memberi isyarat terhadap perkembangan baru populisme di Eropah disamping kemerosotoan idea-idea terkait integrasi regional dan antarabangsa. Lebih separuh daripada pengundi memilih untuk tidak menuruti pandangan mahupun amaran daripada pakar-pakar politik dan ekonomi akan kepentingan pergerakan dan pasaran bebas Eropah sebagaimana yang telah dipraktikkan UK sejak mengganggotai EU. Kerencaman rakyat UK dalam menyokong kempen Leave atau Remain terserlah dengan beberapa faktor seperti jurang pendidikan, demografi, lokaliti, taraf sosioekonomi, konflik dalaman parti utama dan peranan isu-isu post-truth politics yang dimanipulasi oleh kumpulan pro-Leave seperti belanjawan tahunan UK kepada EU dan polemik kemasukan Turki sebagai anggota baharu EU. Sebahagian besar wilayah England (kecuali London) dan Wales mengundi untuk bebas daripada EU, manakala Scotland dan Ireland Utara pula mengundi untuk kekal menjadi anggota EU. Namun apa yang lebih menonjol di sini adalah dua identiti terpisah masyarakat UK yang merasakan kepentingan untuk terus berintegrasi dengan EU dan sebaliknya. Kemenangan kempen Leave pasca Referendum secara tidak langsung telah meningkatkan populariti kumpulan dan parti berhaluan kanan di UK seperti EDL, BNP dan UKIP yang begitu aktif di laman maya dan siri demonstrasi jalanan. Dengan melemparkan retorik serta sentimen kebencian terhadap golongan minoriti dan imigran terutamanya yang bukan berkulit putih, orang Asia dan yang paling menonjol orang Islam - gerakan pelampau kanan dilihat akan terus berkembang pasca Referendum 2016 di atas landasan 'memelihara nilai British' dan kedaulatan UK serta menghalang perkembangan Islamisasi.

\section{Penghargaan}

Mohd Irwan Syazli Saidin merakamkan ucapan terima kasih kepada Exeter City Council di atas kelulusan sebagai pemerhati bebas (no pendaftaran CC-355/1/Commanwealth citizen) semasa Referendum Kesatuan Eropah, 23 Jun 2016 bertempat di Exwick Parish Hall, Exeter, United Kingdom. Kajian ini turut dibantu oleh Dana Penyelidikan UKM, kod GGPM 2020-042.

\section{References}

Allen, C. (2011). Opposing Islamification or Promoting Islamophobia? Understanding the English Defence League. Patterns of Prejudice, 45(4), 279-294.

Akkerman, T. (2003). Populism and Democracy: Challenger or Pathology? Acta Politica, 38, 147 159. 
Ashcroft, L. (2016). How the United Kingdom voted on Thursday... and why. Lord Ashcoft Poll. Retreived from https://lordashcroftpolls.com/2016/06/how-the-united-kingdom-votedand-why/

BBC News. (2013). Conservatives publish EU referendum bill. Retreived from https://www.bbc.com/news/uk-politics-22518403

BBC News. (2019). Fifth of UK's Syrian refugees settled in Scotland. Retreived from https://www.bbc.com/news/uk-scotland-47597458.

Beergren, E., \& Neergard, A. (2015). Populism: Protest, democratic challenge and right wing extremism. Dlm. Dahlstedt, M. \& Neergard, A. International Migration and Ethnic Relations: Critical Perspectives 1st Edition. London, Routledge.

Braouezec, K. (2016). Identifying Common Patterns of Discourse and Strategy among the New Extremist Movements in Europe: The Case of the English Defence League and the Bloc Identitaire. Journal of Intercultural Studies, 37(6), 637-648.

Busher, J. (2018). Why Even Misleading Identity Claims Matter: The Evolution of the English Defence League. Political Studies, 66(2), 323-338.

Camus, J. Y., \& Lebourg, N. (2017). Far-Right Politics in Europe. Cambridge, Harvard University Press.

Curtice, J. (2016). The vote to leave the EU: Litmus test or lightning rod? British Social Attitudes, $34,1-23$.

Deacon, D., \& Wring, D. (2016). The UK Independence Party, populism and the British news media: Competition, collaboration or containment? European Journal of Communication, 31(2), 169-184.

Engström, R. (2018). The (dis)continuation of Scottish nationalism? A discursive comparison of the Scottish National Party and National Collective. Journal of Political Ideologies, 23(1), 97-115.

Financial Times. (20160. Brexit EU Referendum result. Retreived from https://ig.ft.com/sites/ elections/2016/uk/eu-referendum/

Freeden, M. (2016). After the Brexit referendum: revisiting populism as an ideology. Journal of Political Ideologies, 22(1), 1-11.

Gabel, M., \& Palmer, H. D. (1995). Understanding variation in public support for European integration. European Journal of Political Research, 27(1), 3-19.

Green, J., \& Prosser, C. (2016). Party system fragmentation and single-party government: The British general election of 2015. West European Politics, 39(6), 1299-1310.

Haarop, A. (2017). Where next for Labour? The Political Quarterly, 88(3) July-September, 395399.

Harsin, J. (2018). Post-Truth and critical communication studies. Dlm. Oxford Research Encyclopedia, Communication. New York, Oxford University Press.

Hayton, R. (2016). The UK Independence Party and the politics of Englishness. Political Studies Review, 14(3), 400-410.

Henley, J. (2016). Why Vote Leave's $£ 350$ m weekly EU cost claim is wrong. Retreived from https://www.theguardian.com/politics/reality-check/2016/may/23/does-the-eu-really-costthe-uk-350m-a-week

Home Office. (2018). Hate Crime, England and Wales, 2017/18. London: Crown Copyright

House of Commons. (2015). Parliamentary Debates (Hansard) Volume 596 No. 13: Tuesday 9 June 2015. London, Crown Copyright. 
House of Commons. (2016). Briefing Paper CBP7639: European Union Referendum 2016. London, House of Commons Library.

Iakhnis, E., Rathbun, B., Reifler, J., \& Scotto, T. J. (2018). Populist Referendum: Was Brexit an Expression of Nativist and Anti-Elitist Sentiment?. Research and Politics, 5(2), 1-7.

Juncker, J. C. (2014). My Foreign Policy Objectives. Brussels, European People's Party.

Johnston, R., Pattie, C., \& Hartman, T. (2020) Who follows the leader? Leadership heuristics and valence voting at the UK's 2016 Brexit referendum. Innovation: The European Journal of Social Science Research, 1-16.

Keyes, R. (2004). The Post-Truth era: Dishonesty and deception in contemporary life. New York: St. Martin's.

May, A. (1999). Britain and Europe since 1945. London, Routledge.

Moore, L. (2016). Why Conservatives back Brexit (or not). Retreived from https://blog.politics.ox.ac.uk/conservative-mps-back-brexit-not

Norris, P. (2018). Generation wars over Brexit - and beyond: how young and old are divided over social values. Retreived from https://blogs.lse.ac.uk/politicsandpolicy/generation-warsover-brexit/

Office for National Statistics. (2011). QS201EW - Ethnic Group. London, HM.

Reed. M. (2015). Actors in the distance: Rural protests in the UK and the Parliamentary parties. Dlm. Strijker, D., Voerman., G \& Terluin, I. (Eds.), Rural protest groups and populist political parties (pp. 79-100). Amsterdam, Wageningen Academic Publishers.

Reed, M. (2016). 'This Loopy Idea': An analysis of UKIP's social media discourse in relation to rurality and climate change. Space and Polity, 20(2), 226-241.

Roodujin, M. (2014). Vox populisms: a populist radical right attitude among the public? Nations and Nationalism, 20(1), 80-92.

Smith, M., \& Colliver, C. (2016). The impact of Brexit on far-right groups in the UK: Research briefing. London, Institute for Strategic Dialogue.

Stanley, B. (2008). The thin ideology of Populism. Journal of Political Ideology, 13(1), 95-110.

The Guardian. (2013). David Cameron's EU speech - full text. Retreived from https://www.theguardian.com/politics/2013/jan/23/david-cameron-eu-speech-referendum

The Guardian. (2019). Racism rising since Brexit vote, nationwide study reveals. Retreived from https://www.theguardian.com/world/2019/may/20/racism-on-the-rise-since-brexit-votenationwide-study-reveals

The Independent. (2018). British public still believe Vote Leave ' $£ 350$ million a week to EU' myth from Brexit referendum. Retreived from https://www.independent.co.uk/news/uk/ politics/vote-leave-brexit-lies-eu-pay-money-remain-poll-boris-johnson-a8603646.html

The Times. (2018). Far-right leaders 'contacted Darren Osborne before Finsbury Park mosque attack'. Retreived from https:/www.thetimes.co.uk/article/far-right-leaders-tommyrobinson-english-defence-league-and-jayda-fransen-britain-first-contacted-darrenosborne-before-finsbury-park-mosque-attack-776z3wscr

Tony Blair Institute for Global Change. (2019). Narratives of Hate: The spectrum of Far Right worldviews in the UK. Retreived from https://institute.global/policy/narratives-hatespectrum-far-right-worldviews-uk

Tournier-Sol, K. (2015). Reworking the Eurosceptic and Conservative traditions into a populist narrative: UKIP's winning formula? Journal of Common Market Studies, 53(1), 140-56. 